\title{
The Impact of Using Contextual Teaching and Learning (CTL) in Arabic Essay Writing Classes
}

\author{
Muhammad Kamal bin Abdul Hakim, Yumna Rasyid, Zainal Rafli \\ $\left\{\right.$ m.kamal.ah@unj.ac.id ${ }^{1}$, yumna.rasyid@unj.ac.id ${ }^{2}$, zainal.rafli@unj.ac.id $\left.{ }^{3}\right\}$ \\ Language Education, Postgraduate of State University Jakarta Indonesia ${ }^{1,2,3}$
}

\begin{abstract}
The aim of this study is to examine the effect of contextual teaching and learning approach of the Arabic essay writing skills students of Education Arabic Department Faculty of Language and Arts State University of Jakarta. The research was conducted during the second semester in the 2015/2016 academic year starting from February up June in 2016. The study design used Elliot's procedure, which comprised seven phases, namely: (a) identifying the initial ideas, (b) finding and analyzing the facts, (c) general planning, (d) Implementing, (e) observing, (f) evaluating, and (g) revising. The data were taken by observation, interview, daily note, and test. The results of the study found that the mean of the pre-test was 65,30 , the average score results of the test at the first cycle were 73,25 , the average score of the test at the second cycle was 77,40, and the average score of the test at third cycle was 84.1. It concluded that the contextual teaching and learning approach could improve the student's skill in Arabic essay writing.
\end{abstract}

Keywords: Arabic, Essay, CTL, Writing

\section{Introduction}

Writing as one of the language skills and also a way of communicating by expressing the expression of language speakers in the form of written language between one individual and another. Language is used as a means of thinking, expression and means of communication in human life [1]. Writing plays an important role in personal and professional life. Thus, it has become an important component in the University curriculum. Writing in a second language is a difficult area for second language learners. In some countries, the field of writing a second language is a fairly new phenomenon. But historically, the field of writing the second language initially emphasized teaching writing to increase the population of international Second Language (ESL) writers in higher education institutions in North America in the late 1950s and early 1960s. Over the past 50 years, the amount of research on writing a second language has grown rapidly and produced results [2]. But the reality in some Arabic education study programs, writing skills received less attention, for example in the Arabic Language Study Program State University Jakarta, the writing subject / Kitabah only received 8 credits consisting of Kitabah I is 3 credits, Kitabah II is 3 credits, and Kitabah 3 is 2 credits are less than reading and speaking skills each of 10 credits. Kitabah III include writing various kinds of personal and 
official letters; write various kinds of speech texts; write a visit report; writing news texts; writing scientific essays about politics, society and culture. Some of these discussions are included in the scope of academic writing [3].

From the observations made by the researcher as well as the Kitabah III subject, it was continuously found that the quality of learning in the subject for third-year students of the Arabic Language Study Program at State University Jakarta was still relatively weak. This is very evident in the lack of precise vocabulary preparation in the making of sentences, paragraphs and there are still many errors in grammar, and the main point in paragraphs is still biased which makes writing produced by students difficult to understand.

From the results of interviews in pre-research with students about what approach/method usually used by lecturers in Kitabah learning, the majority commented on the direct method. In the learning process in the Kitabah course, the lecturer gives an example from the book, then asks the student to do the assignment, then the lecturer corrects it. According to them, the approach and method used by the lecturers are not appropriate so that they cannot be maximized in encouraging the improvement of student writing skills. During this time, the lecturer used the lecture method in delivering the material so that it lacked the opportunity for students to be actively involved in learning.

This causes the academic writing ability of students in Arabic education programs is still low included the essay writing. The learning process carried out so far has not been able to improve students' essay writing skills optimally and comprehensively. Essay writing requires conscious effort and practice in writing, developing, and analyzing ideas. Students when writing in a second language must have writing skills according to their first strategy, technique and writing skills. Research has shown that students writing ESL are quite different compared to students whose first language is English [4]

Essay writing material learned by sixth-semester students in the Arabic Language Education Study Program includes Maqalah (paper), Taqrir (report), Muraja'ah Kitab (book reference). In this study, researchers only limit essay writing to the writing of papers because indirectly writing papers will greatly assist students in writing the final project/thesis in the seventh semester. The results of the initial test (pretest) which was held on February 16, 2016, obtained an average score of 65.30 students or $65.3 \%$ showed that students' essay writing skills were still low. The details are the average student writing skills in the aspect of ideas is 13.35 with an ideal score of 20 . So, the students' skills in these components are $66.75 \%$. In the organizational component, the average student score is 13.30 . While the ideal score for the component is 20 . Thus, the student's skill in this aspect is $66.50 \%$. In the word selection component, the students' skills only ranged from 10,10 with an ideal score of 15 . Therefore, the students' skills in this component were $67.33 \%$. While on the smooth component of the sentence, the ideal score set is 15 . While the score achieved by students is 10.35 average. Thus, the students' writing skills in these components amounted to $69 \%$. While the component of Coventry, the mean score of students is 2.45 . The ideal score is 5 . The percentage of student skills in the component is only $49 \%$. The opening component of the ideal score paper is 5 while the average score obtained by students reaches 2.45 . The percentage of student skills in the component is $55 \%$. In the component of the contents of the ideal score, paper is 15 while the average score obtained by students reaches 9.65. The percentage of student skills in the component is $64.33 \%$. While the closing component of the ideal score paper is 5 , the average score obtained by students reaches 2.3 . The percentage of student skills in the component is only $46 \%$.

Of the 20 6th semester students in class B, no one gets a score at the limit that is said to be very good, namely $80-89$. As many as 6 (six) students or $30 \%$ got grades between $70-79$ with 
good categories. 10 (ten) students or 50\% of students get grades between 60-69 with enough categories. The $20 \%$ of students scored $50-59$ or 4 people with fewer categories and none of the students in the category was very lacking.

From the observations of researchers on the learning of essay writing and the results of interviews with students that the approach and method used by lecturers so far with lectures and assignments is considered inappropriate because it tends to be monotonous and lacks opportunities for students to be actively involved in learning so that it is less maximal in encouraging students' essay writing skills.

Researchers tried to apply the use of contextual approaches to improve teaching methods deemed inappropriate by students used by lecturers in previous Kitabah learning. Satriani said that the current teaching process still uses a teacher-oriented approach. Teachers as instructors only transfer their knowledge to students actively such as filling bottles until they are full of various knowledge, although sometimes many students do not understand. Teachers are expected to find creative strategies to attract students' attention and practice writing. Contextual approaches can be implemented in delivering writing learning[5].

The application of contextual approaches to academic writing can be known about the results of the improvement, by conducting action research. Several studies related to action research, Arabic essay writing, and contextual approaches have been conducted by outside and domestic researchers. Rahajoe \& Rianto conducted an action research about the ability to write poetry through contextual approaches of children with physical impairments in class XI SMALB, PLB-FIP Surabaya State University [6]. In contextual teaching and learning approach, students will have the way to develop their regulated learning. It is an important aspect of writing. As Bakry and Alsamadani found self-regulation development strategies effective on writing a persuasive essay [7]. While Esnawy found that Jigsaw is used here for reading and introducing research essay writing, but it can be used with any reading passage in any teaching context [8].

From the above explanation, it can be concluded that Arabic essay writing learning can learn using contextual teaching and learning approach that combined with other technique or media of learning. Thus, the study focus on the improvement of Arabic essay writing using contextual teaching and learning approach.

\section{Statement of Problem}

Based on the problem above, the formulation of the problem in this research as follows;

1. How is the process of Arabic essay writing learning through contextual teaching and learning approach?

2. How is the result of improvement Arabic essay writing learning through contextual teaching and learning approach?

\section{Literature Review}

\subsection{Arabic Essay Writing}

Essays writing refers to formal writing. Different opinions arise from Anker that essay is a piece of writing that examines a topic in more depth than a paragraph. Shorts essay may have four or five paragraphs, totalling three hundred to six hundred words. A long essay is six paragraphs or more, depending on what the essay needs to accomplish - persuading someone to do something, using research to make a point, or explaining a complex concept [9]. An essay 
is a short collection of paragraphs that present facts, opinions, and ideas about a topic [10]. So, the essay is a series of paragraphs that have certain meanings and ideas. Topics can be developed from the description of the data found. It is still in their view that the essay has three basic parts, namely introduction, body paragraph, and the conclusion. The introductory paragraph is the first paragraph and the conclusion paragraph is in the final paragraph. While the body of a paragraph consists of several paragraphs. Essay format consists of five paragraphs, including the introductory paragraph to explain the topic, two paragraphs or the development of four paragraphs to explain the topic more clearly and paragraph five is the concluding paragraph.

Essay writing is a part of academic writing. Wallwork argues that academic writing especially researches writing must fulfil several components, namely: title, abstracts (abstract), introduction, review of the literature (quoting references), methods (results), results, discussion, and conclusion [11]. Nazario \& Lewis in Faqih argued [12].

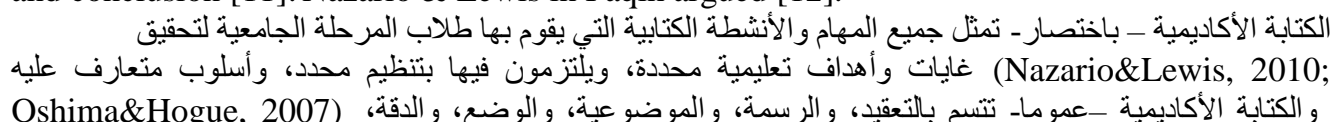
Oshima\&Hogue, 2007)
والمسؤولية (Gillett, 2014)

Academic writing can be briefly defined in all written assignments and writing activities carried out by students to achieve certain educational goals are required to follow the systematics of certain writing and certain pattern. Like as academic writing, essay writing, in general, is complex, official, objective, transparent, accurate and accountable.

\subsection{Contextual Teaching and Learning (CTL)}

Language learning aims to enable students to communicate according to the context of the situation. Language learning emphasizes how students communicate with community members in accordance with the socio-cultural context and social rules, affecting the form of language and behaviour in society. CTL is a holistic system. It consists of interrelated parts that, when interwoven, produce an effect that exceeds what any single part could achieve. Just as the violin, cello, clarinet, and other instruments in an orchestra produce distinctive sounds that together generate music, so CTL's separate parts involve distinctive processes that, when used together, enable students to make connections that generate meaning. Each of these distinct elements of the CTL system contributes to helping students make sense of schoolwork. Taken together, they form a system that makes it possible for students to see meaning in, and retain academic material. The CTL system is education prose that aims to help students see meaning in the academic material they are studying by connecting academic subjects with the context of their daily lives, that is, with the context of their personal, social, and cultural circumstances. To achieve this aim, the system encompasses the following eight components: making meaningful connections, doing significant work self-regulated learning, collaborating, critical and creative thinking, nurturing, the individual, reaching high standards, using authentic assessment [13].

Contextual teaching and learning is a concept that helps the teacher relate the subject matter to a real-world situation. CTL motivates learners to take charge of their own learning and to make connections between knowledge and its application to the various context of their lives as family members, as citizens and workers [14]. The CTL approach is a learning concept that assists the lecturer in linking the material he teaches with the real-world situation of students and encourages students to make connections between the knowledge they have and their application in their lives as family members, communities and workers. 


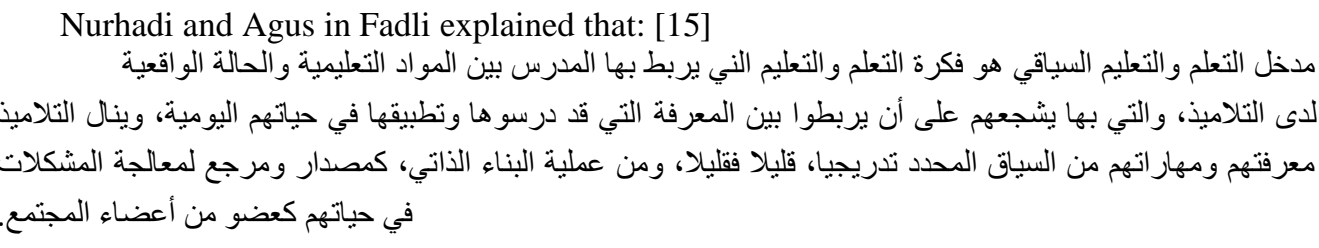

To apply a contextual approach in the classroom, a strategy is needed involving the existing components. There are seven main components of learning that underlie contextual learning in the classroom. "Seven main components of the contextual approach, namely: constructivism, questioning, inquiry, learning community, modelling, authentic assessment, and reflection [15].

More clearly, Jhonson in Widyaningrum explained that CTL is an educational process that aims to help students understand the academic material they learn by connecting academic material with the context of their lives both personally, socially and culturally. This goal can be achieved through eight components: making meaningful relationships, doing meaningful work, doing self-regulated learning, working together, thinking critically and creatively, helping individuals to grow and develop, achieve high standards, and use authentic judgments [16]. Hasani explained that CTL theoretically includes all the recommendations that were previously known. CTL principles can facilitate students to understand instructional subjects and develop creative ideas in the form of writing and making links between academic subjects and real-world contexts [17].

Based on the description above, it can be concluded that CTL is an approach that encourages students to connect the material learned with the real-world context/student environment, in order to be able to find the meaning of what is learned with everyday life so that it is meaningful for themselves as individuals, families, and communities

\section{Methodology}

\subsection{Methods and Procedure}

The study used an action research method that is qualitative and quantitative research. The qualitative method explains the process of learning and the quantitative method analyzed the result of learning. The procedure of research used Elliot that has seven steps of actions, as follow; 1) identification the preliminary problem; 2) reconnaissance; 3) general problem; 4) action implementation; 5) observation; 6) evaluation; and 7) reflection and revising of the action plan. Criteria of action successful have two indicators. The first indicator is

The criteria of action research successful will be determined by two indicators. The first indicator is $80 \%$ of all aspects of the observation in learning process implementation to achieve the criteria of being good enough and good. The second indicator is $80 \%$ of essay writing test has the criteria of good and gets $>70$ test score.

\subsection{Participant of Research}

The participant of research consists of a total 20 students from semester IV from Education Arabic Department Faculty of Language and Arts State University of Jakarta in 2016-2017 academic years. 


\subsection{The Process of Collecting Data}

The process of collecting data as follow;

1. Observation. It takes pre-cycle, and during the process of learning.

2. The test as a result of learning is given before and after the process of-of learning.

3. Daily note

4. Interview

\subsection{The Technique of Data Analysis}

The process of data validity in this research is through triangulation technique using 4 criteria, that are credibility, transferability, dependability, and conformability.

\section{Finding}

\subsection{The Process of Arabic Essay Writing Through Contextual Teaching and Learning (CTL)}

Following is the response of researchers and collaborators in the observation sheet of Arabic essay writing learning activities using a contextual teaching and learning approach for three cycles.

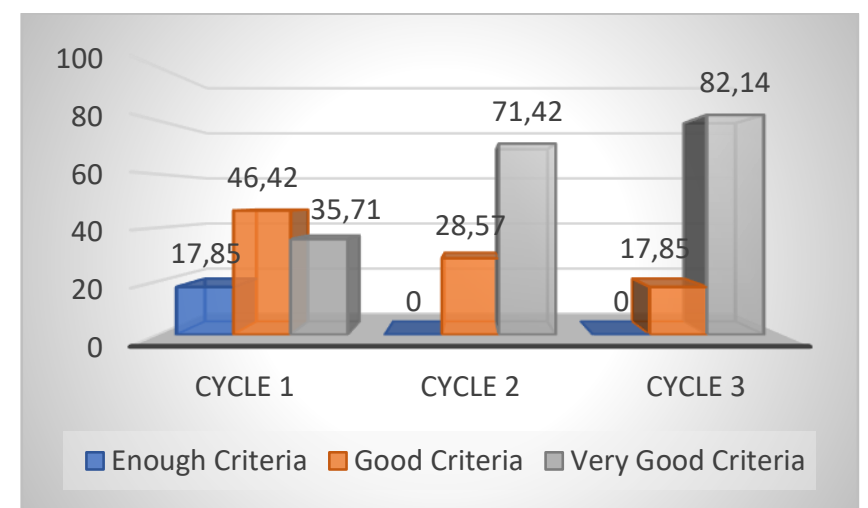

Fig. 1. The result of Collaborators observation on Researchers' Activity from Cycle I to Cycle III

Collaborator observation results on researchers in essay writing learning through contextual teaching and learning approaches by applying seven components namely constructivism, inquiry, questioning, community learning, modelling, authentic assessment, and reflection as follows: In the first cycle, the criteria of "very good" reached $35.71 \%$, criteria "good" $46.42 \%$, and the criteria" enough "17.85\%. In general, the learning process runs optimally although there are still some criteria that are considered to be in the "enough" category. In the second cycle, the criteria of "very good" reached $71.42 \%$, the criteria of "good" $28.57 \%$ and there were no "enough" criteria. The implementation of essay writing learning through contextual teaching and learning approaches are getting better but still needs improvement. In the third cycle, the criteria of "very good" reached $82.14 \%$, the criteria of "good" $17.85 \%$. The implementation of 
essay writing learning through contextual teaching and learning approaches have been very good as indicated by the learning steps taken by researchers on very good criteria that have exceeded $80 \%$.

Based on the collaborator's observations of researchers and observations of researchers on students' activity from cycle I to cycle III shows that essay writing learning through contextual teaching and learning approaches has increased. It is shown in the below graph.

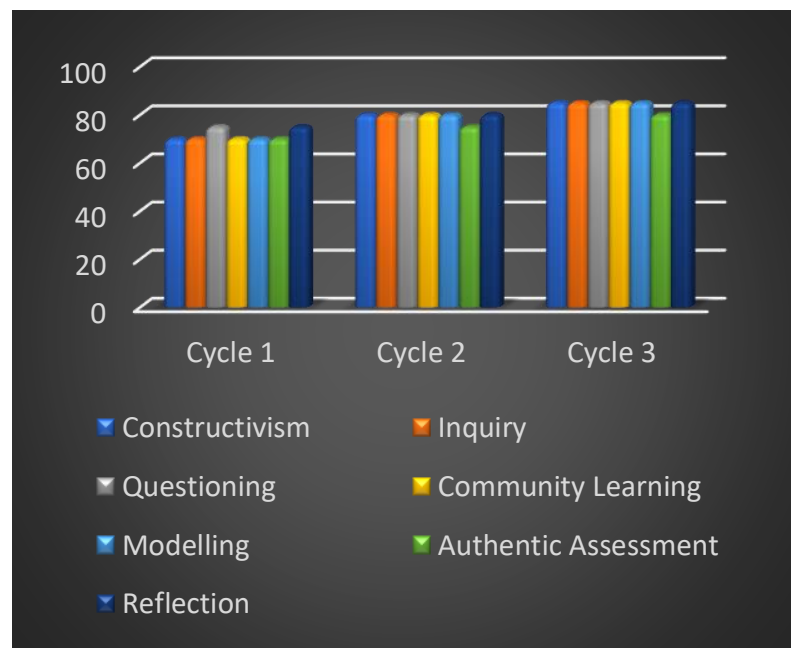

Fig. 2. The Result of Researchers Observations on Students' Activity from Cycle I to Cycle III

The result of researcher observation on students' activity in essay writing learning through a contextual teaching and learning approach by applying seven principles namely constructivism, inquiry, questioning, community learning, modeling, authentic assessment, and reflection as follows; In the first cycle, constructivism components reached $70 \%$ categorized as good, students began to put forward ideas about essay writing material. In the inquiry component, $70 \%$ is categorized as good, some students can do the discovery process about essay writing material. In the $75 \%$ questioning component, categorized as good, some students actively asked questions about essay writing material. While the $70 \%$ of the learning community component is categorized as good, students begin to work together actively to analyze the components of the paper. In the modelling component, only $70 \%$ is categorized as good, students can begin to follow the example of essay writing types. In the authentic assessment component, only $70 \%$ is categorized as good, students can begin to measure and analyze the paper well. In the final principle of reflection, only $75 \%$ is categorized as good, some students can recall what they have learned about essay writing types.

In the second cycle, the constructivism component reached $80 \%$ categorized as very good, most students could express ideas about essay writing material. In the inquiry component, $80 \%$ is categorized very well, most students can do the discovery process about essay writing material. In the $80 \%$ questioning component, it is categorized very well, most students are still passive asking questions about essay writing material. Whereas $80 \%$ of the learning community components are categorized very well, most students can actively work together to analyze the components of the paper. In the modelling component reaching $80 \%$ categorized as good, most students can follow the example of writing an essay type of paper. In the authentic assessment component, only $75 \%$ is categorized as good, some students can measure and analyze the paper 
well. In the last component of reflection, only $80 \%$ is categorized very well, most students can recall what they have learned about writing essay types of papers.

In cycle III, the constructivism component reached $85 \%$ categorized as very good, all students could express ideas about essay writing material. In the inquiry component reaching $85 \%$ is categorized very well, all students can do the discovery process about essay writing material. In the questioning component reaching $85 \%$ is categorized very well, all students actively ask questions about essay writing material. Whereas $85 \%$ of the learning community component is categorized very well, all students can work together actively to analyze the components of the paper. In the modelling component reaching $85 \%$ categorized as good, all students can follow the example of writing an essay type of paper. In the authentic assessment component reaching $80 \%$ is categorized very well, most students can measure and analyze the paper well. In the last principle of reflection, only $85 \%$ is categorized as very good, all students can recall what they have learned about writing essay types of papers

\subsection{The Effectiveness of Visual Mind Mapping in SQ4R Strategy Implementation on English Reading Comprehension Learning}

In the initial test of 20 students, there were 4 people with fewer criteria or $20 \%, 10$ students with enough criteria or 50\%, 6 students with good criteria or $30 \%$, and none of the students with good criteria. Whereas in the final cycle I test, there were 2 students with fewer criteria or $10 \%$, 2 students with enough criteria or $10 \%, 11$ people with good criteria or $55 \%$ and 5 people with very good criteria or $25 \%$. Furthermore, at the end of the second cycle test, there is still 1 student with criteria less or 5\%, 2 students with sufficient criteria or $10 \%, 7$ people with good criteria or $35 \%$ and 10 people with very good criteria or $50 \%$. Whereas in the final cycle III test, there is 1 student with good criteria or $5 \%$ and 19 students with very good criteria or $95 \%$. It is shown in the below graph.

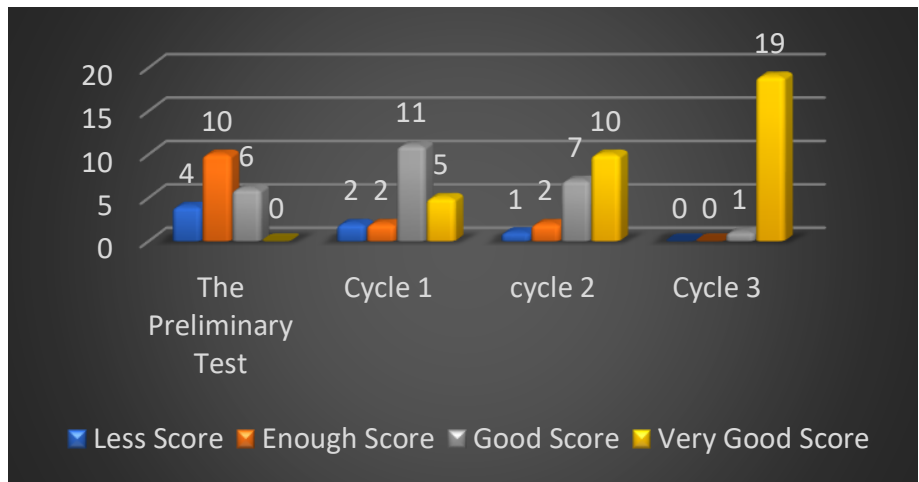

Fig. 3. The Number of Students Who Graduate in Each Category of the Average Score from Cycle I to Cycle III.

The following description attempts to illustrate the expected improvement in students' essay writing skills, based on the components that are the subject of analysis in this study.

1. Component Idea.

The skills of students in all components that are recorded as a whole component (7 components) with a percentage of values that are far from the standard set are only $66.50 \%$. In the first cycle increased to $76.75 \%$ and in the second cycle to $80.25 \%$, and in the third 
cycle to $84.8 \%$. Based on these data, it can be interpreted that the use of contextual approaches can improve student skills in the component of ideas.

2. Organizational Components

In the initial test, the students' skills in all components were recorded as a whole component (7 components) with a percentage value that was far from the specified standard of only $66.50 \%$. In the first cycle it increased to $75.75 \%$ and in the second cycle, it became 78.75 , in the third cycle increased to $83.8 \%$. Based on these data, it can be concluded that the use of contextual approaches can improve student skills in organizational components.

3. Components of Word Selection

In the initial test, the students' skills in all components were recorded as a whole component ( 7 components) with a percentage value that was far from the set standard of only $72 \%$. In the first cycle, it increased to $76.33 \%$. Meanwhile, in the second cycle, it increased to $78.33 \%$, in the third cycle to $85 \%$. Thus, it can be said that the use of contextual approaches can improve student skills in the word selection component.

4. Components of Smooth Sentences

In the initial test, the students' skills in all components were recorded as a whole component (7 components) with a percentage of scores that was only $72.67 \%$. Then in the first cycle, it reached $76 \%$. In the second cycle experienced a very significant increase to $79.67 \%$. In the third cycle, it became $86.3 \%$. Therefore, it can be concluded that through a contextual approach, students' skills in the fluency of sentence components can increase.

5. Components of the Convention

In the initial test, the students' skills in all components were recorded as a whole component (7 components) with a percentage of values that was only $49 \%$. Then in the first cycle, it reached $55 \%$. In the second cycle experienced a very significant increase to $62 \%$, and in the third cycle to $72 \%$. Therefore, it can be concluded that through a contextual approach, students' skills in the convention component can increase even though they have not met the criteria very well.

6. Opening Components

In the initial test, the students' skills in all components were recorded as a whole component (7 components) with a percentage of values that was only $55 \%$. Then in the first cycle, it reached $64 \%$. In the second cycle experienced a very significant increase to $70 \%$ and in the third cycle to $80 \%$. Therefore, it can be concluded that through a contextual approach, students' skills in opening components can increase.

7. Content Components

In the initial test, the students' skills in all components were recorded as a whole component ( 7 components) with a percentage value of only $64.33 \%$. Then in the first cycle, it reached $73.33 \%$. In the second cycle experienced a very significant increase to $78.33 \%$. As well as in the third cycle is to $82.3 \%$. Therefore, it can be concluded that through a contextual approach, students' skills in the content component can increase.

8. Cover Components

In the initial test, the students' skills in all components were recorded as a whole component ( 7 components) with a percentage of the value of only $43 \%$. Then in the first cycle, it reached $59 \%$. In the second cycle experienced a very significant increase to $71 \%$ and in the third cycle to $81 \%$. Therefore, it can be concluded that through a contextual approach, students' skills in the cover component can increase. 


\section{Discussion}

The implementation of this action research has proven that the contextual approach with its seven components, namely constructivism, inquiry, questioning, community learning, modelling, authentic assessment, and reflection can improve the learning process of academic writing. Students can express ideas about essay writing material, can carry out the discovery process about essay writing material, and actively ask questions when a contextual approach is applied. Class nuances that were only centred on lecturers, presented a new nuance for students, who not only seriously worked on the task, but also showed mutual help to fellow group members in the learning community. The contextual approach that has been applied makes students enjoy learning together in groups such as there is no pressure on themselves. The class atmosphere becomes a social structure that helps one another in terms of group cooperation in the learning community because students must discuss in their groups. Students can follow the example of essay writing, together with their group's students can measure and analyze papers well, and can recall what they have learned about essay types of papers.

Although the quality of learning can be improved and have an impact on improving students' skills in writing papers, it still needs further development. This is in accordance with the analysis of the assessment data, there are writing components that still need to be improved, namely the development of ideas, word choices, fluency of sentences, conventions and preliminary structures, contents and conclusions in the papers.

At the first meeting of the first cycle, the process of essay writing learning by applying the contextual approach to the constructivism component. To optimize the process of improving students' skills in essay writing, researchers use LCD and laptops as media in teaching assignments, both in the form of assignments and in group discussions.

At the second meeting, learning activities also used a contextual approach with the inquiry component. In the learning process students are introduced to the writing components that need to be considered in writing papers using LCD, so that they can carry out the discovery process of essay writing material. Furthermore, the learning process at the third meeting, researchers facilitate students to develop leadership, collaboration and information seeking in groups in the learning community and questions. Students in groups must make every effort to determine the title and framework of the paper that each individual will write in the group and discuss with each other. Student cooperation in this activity is very necessary because these activities are limited by time.

After reflection on the results of the first cycle, information was obtained that learning activities designed and implemented through a contextual approach aroused students' enthusiasm for learning. This can be seen from the components of observation on students during the learning process showing concern for learning, activeness in asking questions, activeness in doing assignments, activeness of editing and timeliness of collecting good assignments. However, this has not been able to have implications for the results of improving student writing skills, either individually or classical.

The learning process in the second cycle is carried out through a contextual approach to improve students' skills in essay writing. The CTL learning component used in this cycle is the learning community to improve students' skills in essay types of papers. This learning model facilitates students to communicate within groups to exchange ideas and information. The application of the learning community model is pursued through group division consisting of 5 groups departing 4 people. Before students do learning activities in groups, researchers first review the material about the paper. The researcher distributes the paper containing the title and 
framework of the paper that the student has previously made. The researcher explained again about the shortcomings that still occur in cycle I.

Based on observations from collaborators, the process of increasing student skills in essay types of papers through contextual learning model is very effective to foster collaboration, motivation, self-confidence, independence, and the skills of students. Then, researchers and collaborators need to do the following; first, provide direct corrections to student writing. Second, assign students to more varied essay writing. As well as third, namely optimizing the role of peer tutors in groups.

The learning process in the third cycle still applies a contextual approach but with a different model that is authentic assessment model. The application of the learning model is combined with the process approach. Learning activities begin with the division of student groups like previous meetings. After that, the researchers asked for the results of written papers that had been written beforehand to be analyzed by other groups.

Learning steps in the third cycle, namely (a) Designing the writing framework through group discussion, (b) submitting the writing framework to other groups to avoid similarity in the theme of the paper (c) writing a draft (d) developing the idea of the paper, (e) writing a paper in full, (f) making corrections between groups, (g) rewriting the paper based on corrections from other groups, and (h) submit papers to researchers to be assessed. Through these stages of learning, the process of improving students' skills in writing essay types of papers shows excellent quality, high motivation and concern, great responsibility for the assignments given, as well as good communication and interaction in discussions. Through the results of this study shows that contextual approaches have an impact in improving the learning process of Arabicessay writing skills. This can be seen from the components of the contextual approach which is getting better.

From the findings of the research, it can be said that the action research hypothesis, namely "If a contextual approach is applied, then the student Arabic- essay writing skills will increase" can be accepted. This reinforces similar research, namely Fillner and Apple [18], in their action research on improving writing fluency and lexical complexity through blogs. The study used student blogs in the CALL program integrated to low writing skills, low motivation in Japanese students in intensive English courses for seven days in September 2004. The results of this study concluded that students' writing ability increased significantly over the duration of the program. Abdulkareem [19], in his research on the investigative study of the problem of academic writing faced by Arabic Postgraduate students at Universiti Teknologi Malaysia (UTM). The results of the study present many errors made by students in simple writing assignments. This study discusses in depth the errors that occur in aspects of academic writing and sentence structure in Arabic students.

Al-Asadi in his research on the impact of cultural imperatives on academic writing in the Arab context. The results of the research showed that most of the students in the intervention group achieved an increase in the quality of argumentation compared to peers in the nonintervention group [20]. Nukuhaly conducted a research on improving the ability to write papers for students at the Tarbiyah Faculty of Biology Department IAIN Ambon with modelling strategies. The results of this study that students' ability can be improved through modelling strategies [21]. Rahajoe \& Rianto conducted an action research about the ability to write poetry through contextual approaches with physical impairments in class XI SMALB, PLB-FIP Surabaya State University. The results of this action research showed an increase in the ability to write poetry for children with disabilities class XI SMALB significantly after being given an action using the contextual approach shown in cycle I and cycle II [22]. 
The difference between the results of this study and those studies is on two things, in the process and the results of the improvement of Arabic-essay writing skills through contextual approaches. The process can be seen from the components of the contextual approach, namely constructivism, inquiry, questioning, community learning, modelling, authentic assessment, and reflection used in Arabic essay writing learning which is getting better on observation notes on researchers and students. Likewise, the results of students' skills in essay writing increased significantly both from the components of ideas, organization, word selection, smooth sentence, convention, opening, content, and closing of the cycle to another cycle. When compared with the initial test data, only $64.33 \%$, obtained data regarding the improvement of students' essay writing skills by $83.4 \%$ at the end of cycle III. This research is very important to prove that the use of contextual approaches can improve the learning process and the results of students' skills in Arabic-essay writing. So that the results of this research can be used as a basis for developing teaching materials used previously.

\section{Conclusion}

In the application of the contextual approach to improving Arabic essay writing skills, in reality, it has been able to increase student activeness both individually and classical. Students who experience difficulties in expressing ideas into writing become easier in expressing their ideas in writing, and the process of improving essay writing skills in Arabic becomes even more enjoyable and good cooperation is established between lecturers and students, between students and students during the learning process take place. The problems identified which are the cause of the low skills of students in essay writing have been overcome. These problems are like, it is difficult to find ideas to be written in writing, often run out of words during the writing process, so that the students' skills, in this case, can be improved according to the indicators of success in this study.

The implications of the results of this study can be described as follows:

1. The results of the improvement of Arabic essay writing skills with a contextual approach is as a solution for writing learning, especially essay writing and can be applied to another subject.

2. The method can be used as an alternative to improve the quality of learning for students in writing learning

3. The selection of approaches and methods in the learning process greatly determines the occurrence of the desired skills improvement, adjusting to the lecturers' competence in mastering the approaches and methods used.

4. Evaluation and assessment of Arabic essay writing skills in accordance with the approaches and methods and teaching materials will be able to guarantee the results of the measurement/evaluation of student success rates in the learning process.

5. The results of this study can be a foundation for developing Kitabah III teaching materials specifically relating to an essay or academic writing material.

\section{References}

[1] Sugono, Dendy, Mahir Berbahasa Dengan Benar. Jakarta: PT. Gramedia Pustaka Utama, 2009, p. 4.

[2] Mehrabi, Nastaran, The Effect of Second Language Writing Ability on First Language Writing Ability. Theory and Practice in Language Studies Vol. 4, No. 8, 2014, p.1686. 
[3] Universitas Negeri Jakarta, Buku Pedoman Akademik FBS 2013-2014. Jakarta: UNJ Press,2013, p.275.

[4] Chand, Zakia Ali, Language learning strategy use and its impact on proficiency in academic writing of tertiary students, Procedia - Social and Behavioral Sciences 118, 2014, p.513

[5] Satriani, Intan.el all, Contextual Teaching And Learning Approach To Teaching Writing. Indonesian Journal of Applied Linguistics, Vol. 2 No. 1, 2012, p.11

[6] Rahajoe, Indah Boedi \& Edy Rianto, Kemampuan Menulis Puisi Melalui Pendekatan Kontekstual Anak Tunadaksa Kelas Kelas XI SMALB, PLB-FIP Universitas Negeri Surabaya,ejournal.unesa.ac.id/article/6131/15/article.pdf

[7] Bakry, Mohamed Saad \& Hashem Ahmed Alsamadani, Improving the Persuasive Essay Writing of Students if Arabic as a Foreign Language (AFL): Effects of Self-Regulated Strategy Development. Procedia-Social and Behavioral Sciences Vol.182 No.13, 2015, pp. 89-97

[8] Esnawy, Susan, EFL/EAP Reading and Research Essay Writing Using Jigsaw, Procedia-Social and Behavioral Sciences Vol.232, 2016, pp. 98-101

[9] Anker, Susan, Real Writing with Readings Paragraph and Essays for College, Work, and Everyday Life Fifth Edition. New York: Bedford/ St. Martin's, 2010, p.38

[10] Folse, Keith S. April Muchmore-Vokoun, Elena Vestari Solomon, Great Writing 4; Great Essays Fourth Edition. New York: Cengage Learning, 2014, p. 4

[11] Wallwork, Adrian, English for Writing Research Paper, (New York: Springer, 2011, pp.163-231

[12] Ahmad Faqih, Ahmad Hasan, Istikhdami ma'amil Kitabah fi Internet Litanmiyah Maharat alKitabah was Mu'alajah Musykilah Ta'alummiha Li Tullab al-Marhalah al-Jami'iyyah, International Conference of Technology and Techniques of Education and e-Learning, AlSharjah- UAE 1-3, April 2017 , p. 14

[13] Johnson, Elaine B, Contextual Teaching and Learning, California: Corwin Press Inc, 2002, p.24

[14] Sears, Susan, Contextual Teaching and Learning A Primer for Effective Instruction. Bloomington: Phi Delta Kappa Education Foundation, 2002, p.2

[15] Fadhli, Muhammad, Istikhdam Madkhal at-Ta'allum was at-Ta'lim as-Siyaqi li Tanmiyah Maharah al-Qira'ah. Malang, UIN Maliki, 2010, p.20

[16] Nurhadi, Pendekatan Kontekstual (Contextual Teaching and Learning). Jakarta: Depdiknas, 2002, pp. $20-21$

[17] Widyaningrum, Agnes. Contextual Teaching and Learning (CTL) in ELT English Language Teaching Semarang, Dinamika Bahasa dan Ilmu Budaya Vol. 8. No. 2, 2013, p.16

[18] Hasani, Aceng, Enhancing argumentative writing skill through contextual teaching and learning. Educational Research and Reviews, Vol. 11 No.16, 2016, p. 1575

[19] Fellner, Terry dan Matthew Apple, Developing writing fluency and lexical complexity with blogs. The JALT CALL Journal Vol.2 No.1, 2006,p. 26

[20] Abdulkareem, Mustafa N, An Investigation Study of Academic Writing Problems Faced by Arab Postgraduate Students at Universiti Teknologi Malaysia (UTM). Theory and Practice in Language Studies, Vol. 3, No. 9, September 2013, p. 1557

[21] Al-Asadi, Sami, The Impact of Cultural Imperatives on Academic Writing In Arab Contexts. European Scientific Journal edition vol.11, No.31, November 2015, p. 138

[22] Nukuhaly, Nur Apriani, Kemampuan Menulis Makalah Mahasiswa Jurusan Biologi Fakultas Tarbiyah IAIN Ambon dengan Strategi Pemodelan, Universitas Negeri Malang, Jurnal Pendidikan Humaniora, Volume 1, Nomor 1, Maret 2013, p. 92 